\title{
EXPERIMENTAL STUDIES ON TRYPANOSOMA (SCHIZOTRYPANUM) CRUZI STRAINS ISOLATED FROM MAN, FROM ANIMALS AND FROM TRIATOMINE BUGS IN BRAZIL *
}

\author{
W. B. Petana and J. R. Coura *
}

\begin{abstract}
A study on nine strains of $\mathrm{T}$. cruzi isolated from man, from animals and from triatomine bugs in Brazil are described. The parasites were slightly viscerotropic in white mice in six of the strains, highly viscerotropic and cardiotropic in two strains, and asymptomatic on one strain. Mechanical and cyclical passage from infected to healthy mice, and treatment of the infected mice with immunosuppressant drug, did not increase the blood parasitaemia or strain virulence. The results of biometric studies on the blood trypanosomes from each strain are also described. The various aspects on the importance of T. cruzi strain identification are emphasized and discussed.
\end{abstract}

\section{INTRODUCTION}

Since the picneering work by Chagas $(9,10,11)$ the various aspects of the causative organism Trypanosoma (Schizotrypanum) cruzi have been studied quite extensively. The investigations were directed on the pathological aspects of the parasite as well as on the biological, morphological and immunological characteristics among the various strains. Some comparative studies were also carried out on the differentiation batween Brazilian and other South American strains. In Brazil the following investigators have notably contributed in this field of work: Villella and Torres (32), Campos (8), Dias (14), Nussenzweíg et al. (22, 23), Silva and Nussenzweig (28), Brener $(5,6)$, Brener and Chiari (7), Deane et al. (13), Coura et al. (12), Andrade and Andrade $(1,2)$, Andrade $e t$ al. (3) and Kramer (15). From outside Brazil studies on $T$. cruzi strains from the following countries may be mentioned. Argentina, Belize (British Honduras), Chile, Colombia, Costa Rica, México, Peru, Venezuela and the U.S.A. (3, 4, $17,18,19,20,21,25,26,27,30,31,33,34)$.

One part of our present research project on Chagas' disease in Brazil includes the isolation of $T$. cruzi strains from man, from animals, and from triatomine bugs. The purpose for the study is to compare the behaviour of the isolates under experimental conditions in white mice, inclusive of grade of parasitaemia, virulence, morphological and biometric studies on the blood trypanosomes, organotropism, and pathological alterations in the organs of the infected animals.

\section{MATERIALS AND METHODS}

A total of 12 strains were isolated of which nine were investigated conclusively and are described here. Five of the isolates

* This work was supported by the Overseas Development Ministry in London and by the Conselho Nacional de Pesquisas, Brazil.

Department of Preventive Medicine, Federal University of Rio de Janeiro, Caixa Postal 1859, Rio de Janeiro, Brazil.

Submitted to publication on $6-6-1974$. 
were from human patiens with Chagas' disease, two strains originated from domestic dogs and two isolates were obtained from naturally infected domestic Triatoma infestans. For convenience a brief history of the source from each of the strains was obtained is given below.

Strain No. 1 - Was isolated by xenodiagnosis from 11 years old female in a locality, Piranema, in the municipality of Caxias, close to the city of Rio de Janeiro. The immunofluorescence and complement fixation test (IFT and CFT) were positive. Detailed clinical examination suggested an asymptomatic form of Chagas' disease. In the same household three more children were serologically and parasitologically positive for Cnagas' disease, and from two dogs, living in the same household, T. cruzi was isolated by xenodiagnosis. The presence of domestic $T$. infestans infected with T. cruzzi was also confirmed on several occasions.

Strain No. 2 - Was obtained by xenodiagnosis from eight years old female, also from Piranema. Infection in the child was confirmed serologically and parasitologically. Clinical examination confirmed an asymptomatic form of Chagas' disease. Further four children in the same household were found serologically positive, and from three $T$. cruzi was isolated by xenodiagnosis. The xenodiagosis test, carried out on six dogs living in the same household, was negative. Large number of $T$. infestans were captured in the house, many of them infected with $T$. cruzi.

Strain No. 3 - Originated from 48 years old farmer by xenodiagnosis. The patient also lives in Piranema, and was found serologically positive for Chagas' disease in 1968 and 1971. The infection was diagnosed as asymptomatc, and the man is still engaged in farming. His wife also had a positive serological test for Chagas' disease, but no trypanosomes were isolated from her by xenodiagnosis. The house was searched on several occasions for triatomine bugs, but only once three adult $T$. infestans had been caught, one of which was infected with $T$. cruzi.

Strain No. 4 - Was isolated by xenodiagnosis from a 30 years old female pa- tient, native from Bahia. Clinical examination revealed a chronic chagasic cardiomyopathy and schistosomiasis with $S$. mansoni. The serological test (IFT and CFT) was positive on several occasions over a long period of time.

Strain No. 5 - Originated from a 41 years old female patient by xenodiagnosis. The patient, a native from Bahia, attended our out-patient clinic and was diagnosed for schistosomiasis, and a chronic and asymptomatic form of Chagas' disease. The IFT and CFT were positive on several occasions.

Strain No. 6 and 7 - The strains were isolated by xenodiagnosis from two dogs. The animals belong to the household in Piranema from which the human $T$. cruzi strain no. 1 was obtained.

Strain No. 8 and 9 - Originated from domestic $T$. infestans captured in the two houses in Piranema from which the human T. cruzi strains were isolated (no. 1 and no. 2) .

All the strains were established in adult white mice (Swiss strain), after inoculation with faeces from bugs used in the xenodiagnosis test, and from naturally infected domestic $T$. infestans. The faeces from each group of ten 5th-instar nymphs of $T$. infestans, used in xenodiagnosis, were pooled and suspended in 2.5 $\mathrm{ml}$ of saline solution. In the case of the naturally-infected domestic bugs, the faeces from only three adult $T$. infestans from each house were used, because of the very high gut parasitaemia with $T$. cruzi.

The number of metatrypanosomes in the faeces of bugs used in the xenodiagnosis test on humans and on the dogs was very low. It was estimated that the inoculum of each mouse contained between 30,000 and 50,000 metatrypanosomes in $0.5 \mathrm{ml}$ of the pooled faecal suspension. In the case of the naturally-infected bugs the gut parasitaemia was very much higher, with between 200.000 and 400.000 infective forms per $0.5 \mathrm{ml}$ of the inoculum. Prior to the incculation Giemsa-stained smears were prepared from eachbatch of the faeces for confirmation of 
the parasite morphology. In each case the flagellates were a mixture of epimastigote and metacyclic $T$. cruzi.

Four mice were used for each strain, and were inoculated intraperitoneally with $0.5 \mathrm{ml}$ of the faecal suspension. After the inoculation the mice were divided into two groups. Two mice in group one were investigated every 10 days for blood parasitaemia, and their blood was used for further passage to healthy animals as well as for cyclical passage with $T$. infestans. Thin blood films were prepared from each mouse in group one for morphological and biometric studies of the blood trypanosomes. Because of the very scanty presence of parasites in Giemsa-stained film only 25 trypanosomes were examined and measured in each strain.

The other two mice from each strain in group two were reserved for a long-term observation on the progress of the infection, and their blood was examined only once a month in order not to disturb the animals unduly. At the end of the observation period (between eight months and one year) the mice were subject to a xenodiagnosis test with five 3rd instar $T$. infestans per mouse. Thereafter each mouse was treated for 10 successive days with an immunosuppressant drug (cyclophosphamide), in doses of $50 \mathrm{mg} / \mathrm{kg}$ body weight, inoculated intraperitoneally. This procedure was used to see if the blood parasitaemia or the strain virulence may be increased by blockage of the immuno-defense system. After the treatment the mice were sacrificed and subject to a post mortem examination. A part of the heart muscle, colon and esophagus were prepared for histolcgical scrutiny.

\section{RESULTS}

The course of infection in the mice was generally similar in each strain. A very low blood parasitaemia developed between 10 and 30 days after the inoculation, and the number of trypanosomes remained very scanty on each subsequent examinations, never exceeding more than 20 parasites per whole of the coverslip $(1 \mathrm{~cm} \times 1 \mathrm{~cm})$, using the $40 \times$ dry objective and $\mathrm{x} 10$ eyepiece. The morphology of the blood forms was in each case typical for
T. cruzi. The biometric details of the blood trypanosomes from each strain are summarized in Table 1.

The mice showed no sign of illness or distress, and eventually no trypanosomes could be detected by a direct wet blood film examination from two to four months after the inoculation. Subinoculation of blood from mice in group one to further clean mice, or cyclical passages with $T$. infestans have not increased the blood parasitaemia or strain virulence. The xenodiagnosis test on mice in group two at the end of the observation period was positive in all strains, with exception of strain number nine, where the result was negative. The post mortem and histopathological findings in mice from group two are summarized in Table 2.

The colon in one mouse from strain number seven (dog strain), and in one mouse from strain number eight (bug strain), showed a well pronounced megaly (Plate I, figs. A and B). Both colons contained a mass of hard faeces.

The hearts of mice from strain number seven and eight, both of which had a megacolon, were distinctly enlarged (Plate $I$, figs. C and D). On cross-section both hearts showed enlargement of the ventricular cavity, a thinning of the left ventricular apex, and hypertrophy of the intraventricular septum, mostly on the left side (Plate I, fig. G). In histological sections very scanty and small pseudocysts with amastigote form of $T$. cruzi were seen in both hearts (Plate I, figs. $E$ and $F$ ), as well as a considerable decrease of ganglion cells.

\section{DISCUSSION AND CONCLUSION}

The results obtained suggested that all the strains, with exception of strain number nine, were viscerotropic to a lesser degree in mice from strains number one to six, and in two mice from strain number seven and eight, with a well developed megacolon in one of each mice in strains number seven and eight. Strains number seven and eight were also cardiotropic in the two mice with a megacolon.

The main point of interest is that the megacolon and megaheart developed in 
TABLE 1 - Showing the mean length and the nuclear index (NI) of the blood trypanoscmes from each strain

\begin{tabular}{cccccccccc} 
Strain No & 1 & 2. & 3 & 4 & 5 & 6 & 7 & 8 & 9 \\
\hline $\begin{array}{l}\text { Mean length } \\
\text { (microns) }\end{array}$ & 19.7 & 2.1 .3 & 19.9 & 21.1 & 21.7 & 20.6 & 21.0 & 20.9 & 19.8 \\
\hline NI & 1.6 & 1.7 & 1.2 & 1.7 & 1.6 & 1.2 & 1.6 & 1.7 & 1.4 \\
\hline
\end{tabular}

TABLE 2 - Summarizing the pathclogy and histcpathclogy in mice from each of the nine $T$. cruzi strains

\begin{tabular}{|c|c|c|c|}
\hline Strain N.': & Origin: & Post mcrtem findings: & Histopathclogy: \\
\hline 1 & human & $\begin{array}{l}\text { slight enlargement of } \\
\text { cclon; heart and eso- } \\
\text { phagus normal }\end{array}$ & $\begin{array}{l}\text { a slight decrease } \\
\text { in ganglion cells } \\
\text { in colon }\end{array}$ \\
\hline 2 & human & $"$ & $"$ \\
\hline 3 & human & $"$ & " \\
\hline 4 & l:uman & $"$ & $"$ \\
\hline 5 & human & $"$ & $"$ \\
\hline 6 & $\operatorname{dog}$ & $"$ & $"$ \\
\hline 7 & $\operatorname{dog}$ & $\begin{array}{l}\text { megacolcn and cardiom- } \\
\text { egally; esophagus normal }\end{array}$ & $\begin{array}{l}\text { significant decrease of } \\
\text { ganglion cells in colon } \\
\text { and heart, pseud-ocysts } \\
\text { with } T \text {. cruzi in heart } \\
\text { muscle }\end{array}$ \\
\hline 8 & T. infestans & $"$ & $"$ \\
\hline 9 & T. infestans & all organs normal & no changes \\
\hline
\end{tabular}



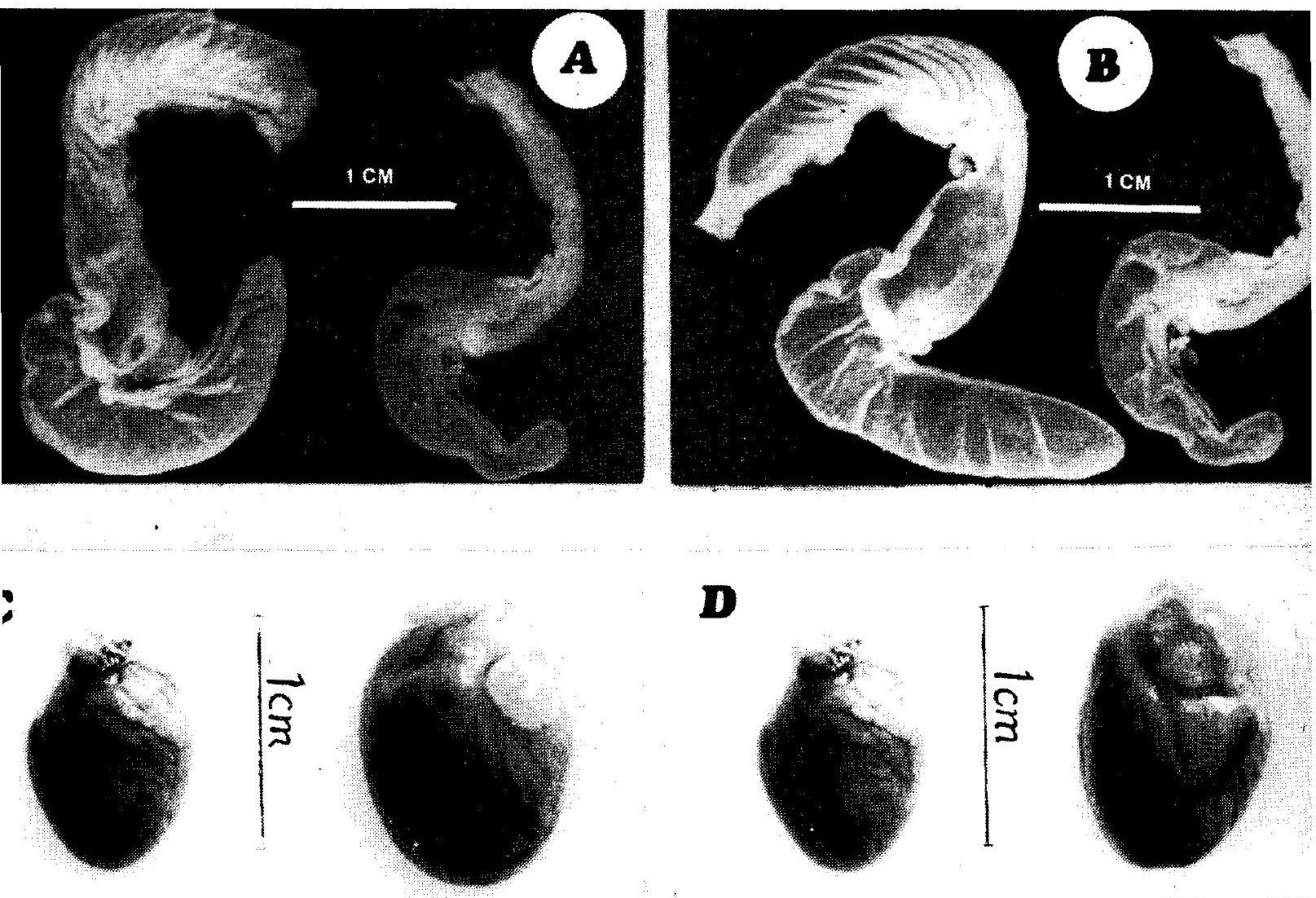

$\mathbf{D}$
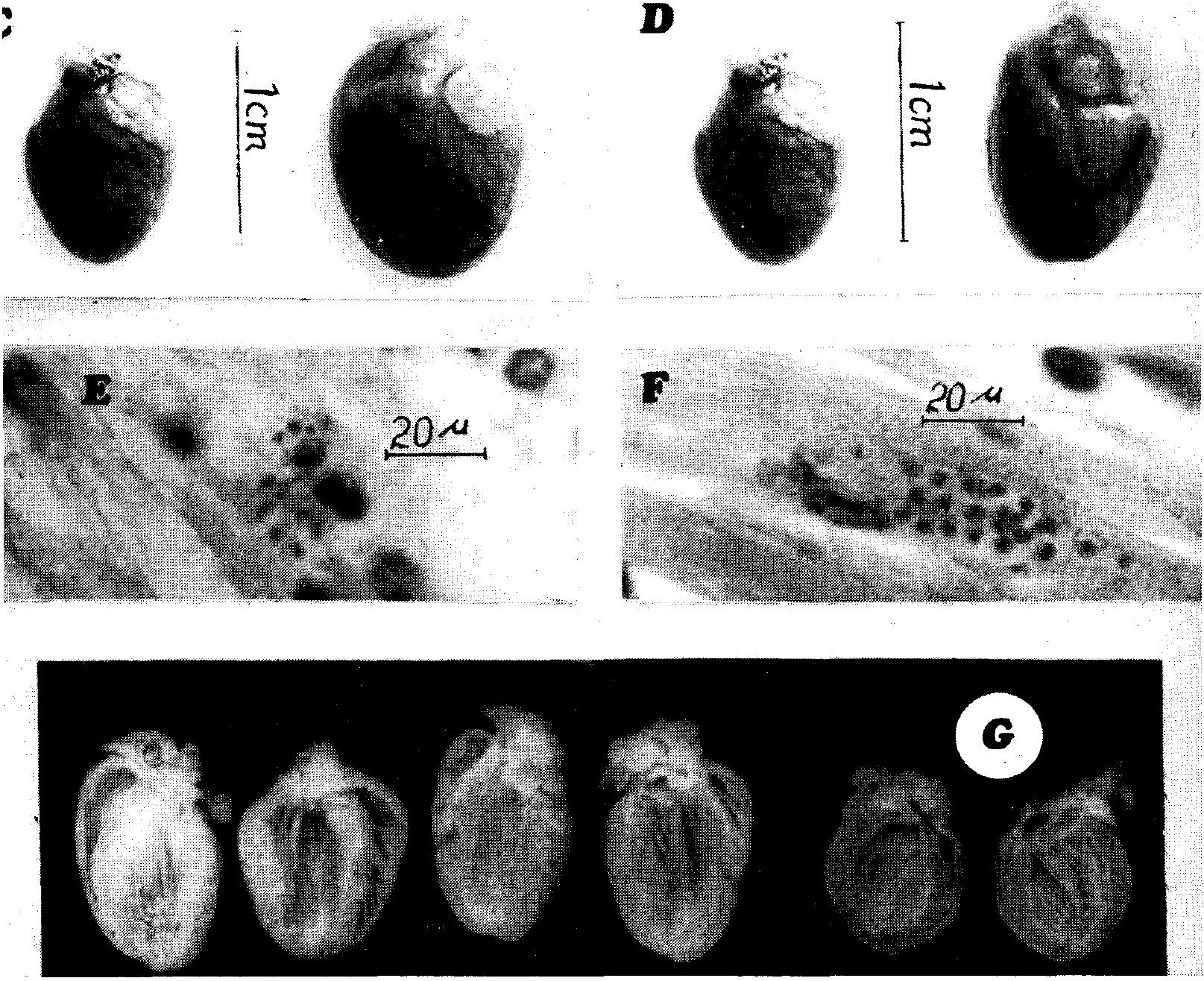

Figs. A and B - show the enlarged colons in mice from strain number seven and number eirht (a colon from a normal mouse of the same age is shown on the right).

Figs. C and D - cardiomegally in mice from strain seven and eight (the heart from a normal mouse of the same age is shown on the left).

Figs. E and $\mathbf{F}$ - a small pseudocyst in the myocardium in mice from strain number seven and eight with amastigote forms of $T$. cruzi.

Fig. G - cross-section of hearts from mice in strain number seven and eipht showin's the cross-pathology of the myocardium as described in the text (a heart from a normal mouse is shown for comparison on the right). 
mice infected with a dog and bug strains of $T$. cruzi. The dog and the insects came from the same household in which four children have been diagnosed serologically and parasitologically for Chagas' disease, but the trypanosomes isolated from one of the children (strain number one) did not produce pathological changes in the mice, comparable with those produced by the non-human strains obtained from the same circle of co-habitation. At the present the children have an asymptomatic form of Chagas' disease, and it is not possible to postulate which course the infection may take after several more years.

An added interest is, why only one mouse should develop such an severe pathological abnormality whilst the other animal, which received an identical inoculum, was free from any cross-pathoiogical changes. A further feature of interest is that the identical pathological abnormality of the heart and of the colon occured in mice one of which received a very small number of parasites, and the other about ten times more in the inoculum.

The negative xenodiagnosis test in the six dogs, living in the same house with infected persons and triatomine bugs, was also of interest as there is no doubt that at some time the dogs must have come into contact with infected triatomines whilst sleeping in the house. If there was a definitive mean of distinguishing $T$. cruzi and its affinity for a specific host, it may be postulated that the strain number nine was a human strain not transferrable to mice or dogs. This assumption is favoured on grounds that the $T$. cruzi isolated from the child (strain number two) did not produce any pathological condition in the mice, nor were there infected dogs in the house, though the dwelling was infested with triatomine bugs with a high rate of infection with T. cruzi.

The peculiarities in the behaviour of $T$. cruzi in the various mammalian hosts, and under experimental condition, are well-known. Unfortunatelly, however, there seems to be no satisfactory explanation for the behaviour of this flagellate from one host to another. Nussenzweig et al. $(19,20)$ divide $T$. cruzi strains from Brazil into two immunologically distinct types, on which basis they offer an explanation for the clinical diversity of Chagas' disease in the various vertebrate hosts. However, it is known how immunologically unstable trypanosomes can become after a series of passages, mechanical or cyclical, or on transfer from one host to another.

A further mean of $T$. cruzi strain identification was suggested by a Panel of the WHO (24). The Panel is of the opinion that the mean nuclear index (NI) for a 'typical' $T$. cruzi is 1.5 with a range of between 1.2 an 1.7. The experts stressed, however, that both in man and in animals some strains have been found with a very low and high NI, and that the variations not appear to be related to the pathogenicity of such strains. The point of interest here is the definition for a "typical" $T$. cruzi, which, it may be assumed, applies to strains of human origin. Such definition is not only arbitrary but also contradictory in several aspects. Since $T$. cruzi is not a specific parasite for man, its pathogenicity, histotropism and the mode of reproduction should be considered of a greater importance than the biometrical features, irrespective if the strain originated from a vertebrate or from an insect host. As shown in Table 1, the nuclear index in the nine strains described here varied between 1.2 and 1.7. This would suggest that each strain could be defined of either human or animal origin. The parasites were isolated from three different hosts, and it would be difficult to decide on biometric grounds which was a 'typical' or 'atypical' T. cruzi.

The movement of infected hosts and vectors, and the interchange of $T$. cruzi by several passages in different hosts and vectors may also affect the virulence of the parasite, and can result in the formation of a 'new strain' as suggested by Ryckman (28) and Lambrecht (16). There is a need for the revision of our concepts of $T$. cruzi strains, and to try to find a definitive and acceptable mean for their identification .

We are unable to offer an explanation on the differences in the strain behaviour found during our present studies. However, it is known that in some human patients 
with Chagas' disease, living in the environment with infected triatomines, some of the affected members of the family may develop a severe form of Chagas' disease, whilst in others the infection may be asymptomatic for life time. The result of our investigation have once again shown the variability of $T$. cruzi under experimental conditions. This complexity among $T$. cruzi strains is perhaps one of the last intricate factors for the true understanding in the biological and therapeutic approaches for the study and control of Chagas' disease.

\section{ACKNOWLEDGEMENTS}

We are grateful to the Overseas Development Ministry in London, and to the Conselho Nacional de Pesquisa in Brazil, for their financial support in our project on Chagas' disease research. Our sincere thanks are due to Professor F. Köberle, of the Faculty of Medicine, Ribeirão Preto, for his valuable help in evaluation of the histological material from infected mice. The technical assistance of Sras. Maria Zulmira Rios and Edna Teixeira are also gratefully acknowledged.

\section{S U M A R I O}

Nove cepas de T. cruzi, 5 isoladas do homem, 2 isoladas do cão e 2 outras isoladas de Triatoma infestans domiciliados, foram estudadas do ponto de vista morfológico e de. sua virulência e patogenicidade para o camundongo, em um período de observação de 8 a 12 meses.

As cinco cepas isoladas do homem mostraram baixa parasitemia quando inoculadas no camundongo e provocaram nesse animal apenas redução dos glânglios mioentéricos do colon e discreto aumento desse órgáo. Das duas cepas isoladas do cão uma provocou megacolon e cardiomegalia no camundongo e a outra comportou-se de forma semelhante às cepas isoladas do homem. Das cepas isoladas do $\mathrm{T}$. infestans uma foi absolutamente avirulenta para o camundongo e a outra provocou redução dos gânglios do colon e do miocárdio, cardiomegalia e megacolon.

Admitem os autores que a passagem "cíclica" de uma cepa de um reservatório para outro possa modificar o seu comportamento, servindo o homem como "reservatório estabilizador" da baixa virulência e patogenicidade das cepàs, pelo menos daquelas isoladas de casos crônicos.

\section{REFERENCES}

1. ANDRADE, S. G. \& ANDRADE, Z. A. - Estudo histopatológico comparativo das lesōes produzidas por duas cepas do Trypanosoma cruzi - O Hospital, 70: 1267, 1966.

2. ANDRADE, S. G. \& ANDRADE, Z. A. - Patologia da doença de Chagas, experimental de longa duração. Rev. Int. Med. Trop. São Paulo, 10: 180, 1968.

3. ANDRADE, S. G., CARVALHO, M. L., \& FIGUEIRA, R. R. - Caracterização morfobiológica e histopatológica de diferentes cepas do Trypanosoma cruzi. Gaz. Med. Bahia, 70: 32, 1970.

4. BICE, D. E. \& ZELEDON, R. - Comparison of infectivy of strains of
Trypanosoma cruzi (Chagas, 1909). J. Parasit., 56: 663, 1975.

5. BRENER, Z. - Comparative studies of different strains of Trypanosoma cruzi. Ann. Trop. Med. Parasit., 59: 19,1965 .

6. BRENER, $Z$. - The behaviour of slender and stout forms of Trypanosoma cruzi in blood stream of normal and immune mice. Ann. Trop. Med. Parasit., 63: 171, 1969.

7. BRENER, Z. \& CHIARI, E. - Variações morfológicas observadas em diferentes amostras de Trypanosoma cruzi. Rev. Inst. Med. Trop. São Paulo, 5: 220, 19.63. 
8. CAMPOS, E. S. - Estudos sobre uma raça neurotrópica de Trypanosoma cruzi. Ann. Fac. Med. Univ. S. Paulo, 2: $197,1927$.

9. CHAGAS, C. - Nova espécie mórbida do homem produzida por um trypanozoma (Trypanosoma cruzi). Nota prévia. Bras. Méd., 23: 161, 1909.

10. CHAGAS, C. - Ueber eine neue Trypanosomiasis des Menschen. Studien ueber Morphologie und Entwicklungszylus des Schizotrypanum cruzi, n.sp., n.gen., Erreger einer neuen Krankheit des Menschen. Mem. Inst. Oswaldo Cruz, 1: 159, 1909.

11. CHAGAS, C. - Nova entidade mórbida do homem. Resumo geral dos estudos etiológicos e clínicos. Mem. Inst. Oswaldo Cruz, 3: 219, 1911.

12. COURA, J. R., FERREIRA, L, F. \& RUBENS, J. - Tripanosoma do "complexo cruzi" em reservatórios silvestres do Estado da Guanabara. Estudo de sua patogenicidade. Rev. Inst. Med. Trop. São Paulo, 8: 125, 1966.

13. DEANE, M. P., BRITO, T. \& DEANE, L. M. - Pathogenicity to mice of some strains of Trypanosoma cruzi isolated from wild animals of Brazil. Rev. Inst. Med. Trop. São Paulo, 5. 225, 1963.

14. DIAS, E. - Estudos sobre o Schizotrypanum cruzi. Mem. Inst. Oswaldo Cruz, 28: 1, 1934

15. KRAMER, A. W., Jr. - Experimental Chagas' disease in pure bred beagle dogs acutely infected with Trypanosoma cruzi (B strain). Rev. Inst. Med. Trop. São Paulo, 14: 291, 1972 .

16. LAMBRECHT, F. L. Biological variations in trypanosomes and their relation to the epidemiology of Chagas' disease. Rev. Inst. Med. Trop. São Paulo, 7: 346, 1965.

17. MARSDEN, P. D. - Trypanosoma cruzi infection in CFI mice. Mortality with different doses of trypanosomes. Ann. Trop. Med. Parasit., 16: 57, 1967.

18. MARSDEN, P. D., VOLLER, A., SEAH, S. K. K., HAWREY, C. \& GREEN, D. - Behaviour of a Peru strain of Trypanosoma cruai in Rhesus monkeys. Rev. Soc. Bras. Med., Trop., 4: $177,1970$.

19. MAZZOTTI, L. - Variations in virulence for mice and guinea pigs in strains of Trypanosoma cruzi, Chagas from different species of bugs from different localities in México. Am. J. Hyg., 31: 67, 1940.

20. NIÑO, F. L. - Aspectos morphologicos del Schizotrypanum cruzi en los organismos de sus huespedes y en los de medio cultivo. 4. Reun. Soc. argent. Patol. reg. N. Santiago del Estero - 600 .

21. NORMAN, L., BROOKE, M. M., ALLAIN, D. S., and GORMAN, G. W. - Morphology and virulence of Trypanosoma cruzi - like hemoflagellates isolated from wild mammals in Georgia and Florida. J. Parasit., 45: 457, 1959.

22. NUSSENZWEIG, V., DEANE, L. M., \& KLOETZEL, $K$. - Divarsidade na constituição antigenica de amostras de Trypanosoma cruzi isoladas do homem e de bambás. Rev. Inst. Med. Trop. São Paulo, 4: 409, 1962.

23. NUSSENZWEIG, V., DEANE, L. M. and KLOL'TZLL, $K$. - Differences in antigenio ccnstitution of strains of Trypanosomo cruzi. Exp. Parasit., 14: $221,1963$.

24. PAN AMERICAN HEALTH ORGANIZATION (WHO) - Technical Report Ser. 202, Washington, D. C., 1960

25. PETANA, W. B. - Chagas' disease in British Honduras, Central America. Ph. D. Thesis, University of Liverpoll, May 1969. 235 p.

26. PETANA, W, $B$ - - A revision of Trypanosoma (Schizotrypanum) cru$z i$ strains from British Honduras, and the importance of strain characteristics in experimental chemotherapy of Chags' disease. Trans. Roy. Soc. Trop. Med. Hyg., 66: 463, 1972.

27. PIZZI, P. T . and PRAGER, S. R. Estabilizacion de la virulencia de uma cepa de Trypanosoma cruzi por passages seriadas en ratones de constitucion genetica uniforme: analisis auantitativo del curso de la infecion. Biologia, 16-17: 3, 1953 .

28. RYCKMAN, R. E. - Epizootiology of Trypanosoma cruzi in southwestern North America. Part V - Host parasite specificity between $T$. cruzi and Triatominae. J. Med. Ent., 2: 96, 1965 .

29. SILVA, L. H. P. \& NUSSENZWEIG, V. - Sobre uma cepa de Trypanosoma cruzi; altamente virulenta para o 
camundongo branco. Folia Clin. Biol., 20: 191, 1953.

30. TAY, J., GUTIERREZ-Q., SALAZARS. P. M., CASTILLO, M., \& ORTEGA-G, M. - Estudios sobre seis cepas mexicanas de Trypanosoma cruzi. Rev. Inv. Salud Publ. (México), 33: 67, 1973 .

31. VELASQUES, A. A. - Evolucion comparativa de la parasitemia de dos cepas de Schizotrypanum cruzi en ratones. Observacionesac de su letalidad. Acta Med. Venez., 15: 132, 1968.
32. VILLELLA, E. \& TORRES, C. M. Estudos histopatológicos do sistema nervoso central na paralisia experimental pelo Schizotrypanum cruzi. Mem. Inst. Oswaldo Cruz, 19: 175, 1926.

33. WATKINS, R. - Comparison of infections produced by two strains of Trypanosoma cruzi in mice. J. Parasit., 52: 958, 1966.

34. ZELEDON, R. - Neurotropism in Costa Rican strains of Trypanosoma cruzi. J. Parasit., 58: 180, 1972. 